\title{
Apoptotic effect of a novel kefir product, PFT, on multidrug-resistant myeloid leukemia cells via a hole-piercing mechanism
}

\author{
MAMDOOH GHONEUM $^{1}$ and JAMES GIMZEWSKI ${ }^{2}$ \\ ${ }^{1}$ Department of Otolaryngology, Charles R. Drew University of Medicine and Science, Los Angeles, \\ CA 90059; ${ }^{2}$ Department of Chemistry and Biochemistry, University of California, Los Angeles (UCLA), \\ California Nanosystems Institute at UCLA, Los Angeles, CA 90095, USA
}

Received September 13, 2013; Accepted October 29, 2013

DOI: $10.3892 / \mathrm{ijo} .2014 .2258$

\begin{abstract}
We examined the apoptotic effect of a novel Probiotics Fermentation Technology (PFT) kefir grain product; PFT is a natural mixture composed primarily of Lactobacillus kefiri P-IF, a specific strain of $L$. kefiri with unique growth characteristics. The aim of this study was to examine the apoptotic effect of PFT on human multidrugresistant (MDR) myeloid leukemia (HL60/AR) cells in vitro and explore the mechanistic approach underlying its effect. HL60/AR cells were cultured with PFT (0.6-5.0 mg/ml) for 3 days. The apoptotic effect of PFT was assessed through examination of percent apoptosis, caspase 3 activation, Bcl-2 expression levels and changes in mitochondrial membrane potential (MMP). PFT induced apoptosis in HL60/AR cells in a dose-dependent manner which was maximal at $67.5 \%$ for $5 \mathrm{mg} / \mathrm{ml}$. Induction of apoptosis was associated with activation of caspase 3, decreased expression of Bcl-2 and decreased polarization of MMP. In addition, PFT showed a unique characteristic of piercing holes in HL60/AR cells, as indicated by AFM studies. This hole induction may be responsible for the apoptotic effect on cancer cells. These results suggest that PFT may act as a potential therapy for the treatment of MDR leukemia.
\end{abstract}

\section{Introduction}

Lactic acid bacteria (LAB) have been used throughout history to produce fermented food and milk products. In the early 1900s, biologist Eli Metchinkoff suggested that the intake of LAB could increase the life span of humans (1). His findings have been verified by many scientists who have found that

Correspondence to: Dr Mamdooh Ghoneum, Department of Otolaryngology, Charles R. Drew University of Medicine and Science, 1621 E. 120th Street, Los Angeles, CA 90059, USA

E-mail:mghoneum@ucla.edu

Key words: Lactobacillus kefiri, apoptosis, HL60/AR cells, caspase ingesting LAB fermented products provides many benefits for maintaining health $(2,3)$. LAB strains present in fermented milk are normal components of intestinal microflora and help maintain a healthy balance of probiotic bacteria while reducing pathogenic bacteria $(4,5)$. In addition to gut maintenance, LAB have more recently been tested to treat a variety of diseases including Crohn's disease, rheumatoid arthritis and cancer (6).

The idea of treating cancers with LAB is not as recent as one might think. Over a century ago, Metchnikoff suggested that LAB had a protective effect against colorectal cancer (7). However, it is the recent resurgence of research concerning the microbiotic influence on human health that has spurred researchers to confirm Metchnikoff's findings on the anticancer ability of LAB in animal models and to expand understanding of LAB's influence on the cellular environment (8-12). Additional research has shown that LAB also exerts anticancer activity against other types of cancer such as breast and ovarian cancer (13-17).

Conventional treatments for cancer such as chemotherapy aim to initiate apoptosis. However, these drugs can be toxic and can decrease a cancer patient's quality of life. Therefore, there has been an effort to investigate alternative treatments that have fewer side effects and improve the health of the patient. A recent study has shown that Lactobacillus reuteri enhanced tumor necrosis factor (TNF)-induced apoptosis in human chronic myeloid leukemia-derived cells (18) and that bacterial soluble factors secreted by Lactobacillus casei rhamnosus caused induction of apoptosis in human monocytic leukemiacell line, THP-1 (19). These data suggest that fermented milk products and/or the fermentative bacteria themselves may have chemoprotective effects without the toxic side effects of conventional therapeutic drugs.

The product we use in this study is a symbiotic microbe of lactic acid bacteria and yeasts known as Probiotics Fermentation Technology (PFT) kefir grain product. PFT is separated from kefir, a popular drink across Eastern and Northern Europe and Russia. Kefir has been shown to have various health benefits, for example, it protects the intestine against disease-causing bacteria (20) and its kefiran component was shown to lower high blood pressure and reduce serum cholesterol levels in rats (21). PFT mainly contains a unique Lactobacillus kefiri 
P-IF (L. kefiri P-IF) strain that has a unique DNA sequence and shows a $99.6 \%$ homology with regular kefiries and similar $16 \mathrm{~S}$ ribosome sequence compared with other L. kefiri strains. Although strain P-IF shares many common characteristics with other L. kefiri strains, P-IF also has many distinct features that may contribute to its effectiveness as an anticancer agent (Table I) (22). Unlike other L. kefiri strains, P-IF utilizes galactose as a carbon source and produces carbonic acid when its growth medium is agitated. Most L. kefiri strains grow in a lengthwise-dimensional pattern, however, P-IF grows threedimensionally, which is attributed to the unique carbohydrate chains on its surface (22).

The results of this study show that PFT possesses the ability to pierce holes in MDR human myeloid leukemic (HL60/AR) cells, which induces apoptosis in the cancer cells by intrinsic (mitochondrial) pathway of apoptosis. This study suggests that PFT may exert a therapeutic effect in treating MDR cancers.

\section{Materials and methods}

Tumor cell line and culture conditions. Human multidrugresistant (MDR) myeloid leukemia (HL60/AR) cells were used in the present study. Cells were kindly provided by Dr S. Gollapudi at the University of California, Irvine, CA, USA. Tumor cells were maintained in our laboratory in a complete medium (CM) that consisted of RPMI-1640, $10 \%$ fetal calf serum (FCS), $2 \mathrm{mM}$ glutamine and $100 \mu \mathrm{g} / \mathrm{ml}$ streptomycin and penicillin.

Drugs and chemicals. 3-[4,5-dimethylthiazol-2-yl]-2,5-diphenyltetrazolium bromide (MTT) (Sigma-Aldrich, St. Louis, MO, USA), was employed.

Probiotics Fermentation Technology (PFT) kefir grain product. PFT is a mixture that mainly $(\sim 90 \%)$ contains a freeze-dried form of heat-killed L. kefiri P-IF; it is a specific strain of LAB that has a unique DNA sequence and PET scans show a $99.6 \%$ homology with regular kefiries. Characteristics of L. kefiri P-IF are shown in Table I and Fig. 1. PFT also contains 2-3\% each of bacterial strain, Lactobacillus kefiri P-IF and Lactobacillus kefiri P-B1 and three yeast strains, Kazachstania turicensis, Kazachstania unispora and Kluyveromyces marxianus (22). PFT was provided by Paitos Co., Ltd. Yokohama, Kanagawa, Japan.

Detection of cancer cell viability using propidium iodide. HL60/AR cells were cultured in the presence or absence of PFT at different concentrations $(0,0.6,1.25,2.5$ and $5 \mathrm{mg} /$ $\mathrm{ml}$ ) for 3 days and the percentage of dead cancer cells was examined by the propidium iodide (PI) technique using a FACScan flow cytometery. Briefly, PI was added to the cells $\left(1 \times 10^{6} / \mathrm{ml}\right)$ to give a final PI concentration of $50 \mu \mathrm{g} / \mathrm{ml}$. The cells were stained for $30 \mathrm{~min}$ at room temperature in the dark and analyzed by FACScan (Becton-Dickinson, San Jose, CA, USA).

Expression of $\mathrm{Bcl}-2$. For detection of Bcl-2, cells were first fixed and permeabilized with ice-cold $70 \%$ methanol. Cells were then stained with FITC-labeled anti-Bcl-2 or isotype control (Dako Corp., Carpinteria, CA, USA), washed and
Table I. L. kefiri P-IF strain characteristics.

\begin{tabular}{ll}
\hline Test & \multicolumn{1}{c}{ P-IF characteristic } \\
\hline Lactobacillis kefiri & $99.6 \%$ sequence homology \\
& $16 \mathrm{~S}$ ribosome identification \\
Cell shape & Rod \\
Gram staining & + \\
Motility & Non-motile \\
Colony growth & $3 \mathrm{D}$ growth \\
Carbon utilization & Glucose \\
& Fructose \\
& Galactose \\
& L-arabinose \\
& Ribose \\
& Maltose \\
& Lactose \\
& Melibiose \\
pH tolerance & Gluconate \\
& Carbonic acid gas ${ }^{\mathrm{a}}$ \\
& $>4.3 \mathrm{pH}^{\mathrm{a}}$ \\
\hline
\end{tabular}

${ }^{\mathrm{a}}$ Characteristics not common in other kefiri strains.

analyzed by FACScan. The percentage of cells expressing Bcl-2 and mean fluorescent intensity (an indicator of density of the molecules/cell) was determined.

Intracellular activity of caspase 3. The method for measuring intracellular activity of caspase 3 is based on carboxyfluorescein labeled fluromethyl ketone (FMK)-peptide inhibitors of caspases. These inhibitors are cell permeable and non-toxic. Once inside the cells, these inhibitors bind covalently to the active caspase. Caspase-positive (+) cells are distinguished from caspase-negative (-) cells with the aid of flow cytometry. Briefly, cells undergoing apoptosis were loaded with fluorescein labeled FAM-DEVD-FMK for caspase 3 (Intergen Co., NY, USA). After 1-h incubation, the cells were washed to remove unbound caspase and cells that contained bound inhibitor were quantified using a FACScan flow cytometer.

Detection of mitochondrial membrane potential (MMP). Variations of the mitochondrial transmembrane potential $\Delta \Psi \mathrm{m}$ during apoptosis were studied using tetramethylrhodamine ethylester (TMRE, Molecular Probes, Eugene, OR, USA). Briefly, after treatment with PFT for 3 days, cancer cells $\left(5 \times 10^{5}\right.$ cells $\left./ \mathrm{ml}\right)$ were incubated with $50 \mathrm{nM}$ TMRE for $30 \mathrm{~min}$ at $37^{\circ} \mathrm{C}$. The cells were washed with PBS and analyzed with FACS Forward, the side scatters were used to gate and exclude cellular debris using a FACScan. The cells were excited at $488 \mathrm{~nm}$ and the emission was collected on the FL2 channel. Five thousand cells were analyzed. The data were acquired and analyzed using CellQuest software (Becton-Dickinson).

AFM imaging. HL60/AR cells $\left(1 \times 10^{6}\right.$ cells $\left./ \mathrm{ml}\right)$ were cultured with PFT ( $5 \mathrm{mg} / \mathrm{ml})$ for $2 \mathrm{~min}$ and $24 \mathrm{~h}$. Results were compared 


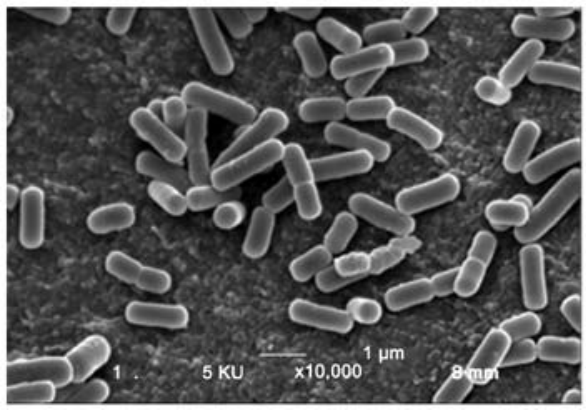

Figure 1. L. kefiri P-IF can grow in three dimensions. Electron microscope image of $L$. kefiri P-IF strain. L. kefiri P-IF are rod-shaped bacteria that uniquely adhere to one another in all three dimensions.

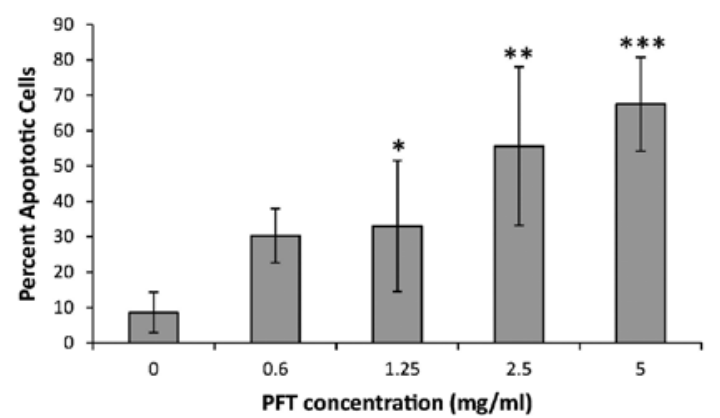

Figure 2. PFT induces apoptosis of HL60/AR cells. Tumor cells were cultured with PFT at different concentrations $(0,0.6,1.25,2.5$ and $5 \mathrm{mg} / \mathrm{ml})$ and the percentage of dead cancer cells was examined by the propidium iodide (PI) technique using a FACScan flow cytometry. Data represent the mean \pm SD of 4 experiments. Statistical analysis compared the concentrations to control $(0 \mathrm{mg} / \mathrm{ml}) .{ }^{*} \mathrm{p}<0.05,{ }^{* *} \mathrm{p}<0.0005,{ }^{* * *} \mathrm{p}<0.0001$

to those of cells without treatment. Cytospin preparations (Shandon Southern Inst., Sewickley, PA, USA) of cells were air-dried, fixed in $100 \% \mathrm{MeOH}$ for 5 min and prepared for AFM studies. AFM studies were carried out to examine the morphological changes associated with PFT treatment of HL60/AR cells such as hole induction and membrane blebbing. Dimension 5000 AFM (Veeco) under contact mode was used to image the HL60/AR cells with Bruker's Sharp Nitride Lever (SNL) silicon probes (Veeco). Topographic height images were recorded at $512 \times 512$ pixels at a scan rate of $0.8 \mathrm{~Hz}$. Image processing was performed using SPIP ${ }^{\mathrm{TM}}$ Software. Usually an MLCT-AFM tip (with a ' $\mathrm{k}$ ' value of $0.03 \mathrm{~N} / \mathrm{m}$ ) contributes to the broadening effect because of its specific geometry (23).

Statistical analysis. Statistical significance for cell apoptosis in Fig. 2 was determined by Student's t-test. Differences were considered significant at the $p<0.05$ level. Statistical analysis for flow cytometry was performed by the Kolmogorov-Smirnov test using CellQuest Software system. A D-value of $>0.2$ was considered statistically significant.

\section{Results}

Effect of PFT on tumor cell survival. We examined the effect of PFT on tumor cell survival using propidium iodide and FACScan flow cytometry. The data in Fig. 2 demonstrate that

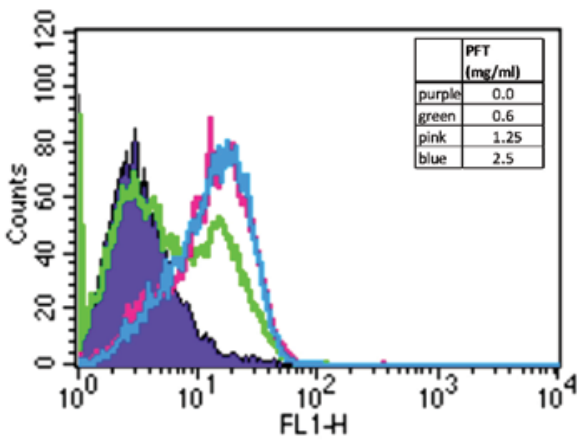

Figure 3. PFT induces apoptosis through activation of caspase 3 . The activation of caspase 3 was determined in cancer cells post-culture with PFT at different concentrations $(0,0.6,1.25$ and $2.5 \mathrm{mg} / \mathrm{ml})$. The lines represent cancer cells in the absence of PFT (control, purple) and cancer cells treated with PFT at concentration of $0.6 \mathrm{mg} / \mathrm{ml}$ (green), $1.25 \mathrm{mg} / \mathrm{ml}$ (pink), or $2.5 \mathrm{mg} / \mathrm{ml}$ (blue). The activation of caspase 3 in cells was detected using carboxyfluorescein-labeled cell permeable peptide substrate and was analyzed using flow cytometry.

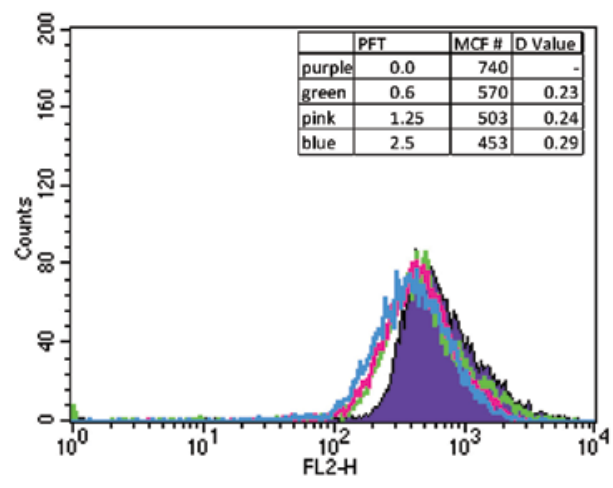

Figure 4. PFT reduces MMP. Tumor cells were cultured with PFT at different concentrations $(0,0.6,1.25$ and $2.5 \mathrm{mg} / \mathrm{ml})$ and the MMP was determined by flow cytometry using TMRE dye. Decrease in TMRE fluorescence indicates loss of membrane potential. PFT depolarized membrane potential in a dose-dependent manner. Statistical analysis was performed by the Kolmogorov-Smirnov test using CellQuest Software System. A D-value >0.2 is considered statistically significant.

treatment with PFT increased apoptosis in the cancer cells in a dose-dependent manner. Even at a lower concentration $(0.6 \mathrm{mg} / \mathrm{ml})$, the PFT induced apoptosis in $~ 30 \%$ of the HL60/ AR cells. The percentage of apoptosis continued to increase in conjunction with higher concentrations of PFT reaching an average of $67.5 \%$ apoptosis at $5 \mathrm{mg} / \mathrm{ml}$.

PFT induces activation of caspase 3. To verify activation of the apoptotic pathway, the level of caspase 3 activation was investigated by treating HL60/AR cells with PFT at varying concentrations for $24 \mathrm{~h}$ and analyzed using flow cytometry. Data depicted in Fig. 3 show that the proportion of cancer cells with increased active caspase 3 was higher in PFT-treated cells than in control untreated cells. This would suggest that pre-exposure of HL60/AR cells to PFT led to increased activation of the executioner caspase 3 .

PFT depolarizes mitochondrial membrane potential (MMP). Experiments were carried out to examine the ability of PFT 


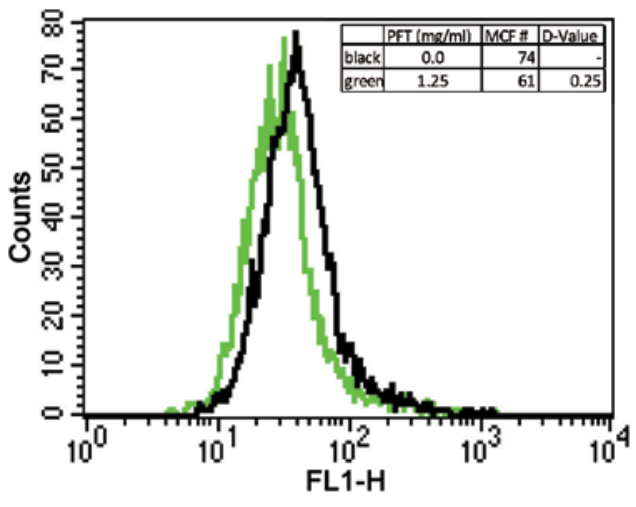

Figure 5. PFT reduces the expression of Bcl-2. HL60/AR cells $\left(1 \times 10^{6}\right.$ cells $\mathrm{ml}$ ) were cultured with PFT at a concentration of $1.25 \mathrm{mg} / \mathrm{ml}$ for $24 \mathrm{~h}$. Expression of Bcl-2 was determined by staining the cells with anti-human Bcl-2 antibody and by flow cytometry. It is shown as mean fluorescent intensity $(\mathrm{MCF})$.

to disrupt MMP. HL60/AR cells were treated in the presence or absence of PFT at varying concentrations and MMP was determined by flow cytometry using membrane potential sensitive TMRE dye. The data in Fig. 4 show that treatment of cells with PFT resulted in a significant decrease in the mitochondrial polarization of cancer cells as compared to untreated cells.
Expression of $\mathrm{Bcl}-2$. The expression of $\mathrm{Bcl}-2$ was examined to determine the anti-apoptotic activity post-treatment of HL60/ AR cells by PFT. Results depicted in Fig. 5 show that treatment with PFT caused a statistically significant decrease in expression of Bcl-2 compared to control cancer cells without treatment.

AFM studies. AFM studies were carried out to examine the morphological changes associated with PFT treatment of HL60/AR cells. Results showed a low percentage of the control untreated HL60/AR cells with holes, as well as a small number of holes per cell (Fig. 6A). When the cancer cells were exposed to L. kefiri P-IF ( $5 \mathrm{mg} / \mathrm{ml})$ for $2 \mathrm{~min}$, we observed an adherence of L. kefiri P-IF to the cancer cells (Fig. 6B). Exposure of cancer cells to L. kefiri P-IF for a longer time $(24 \mathrm{~h})$ resulted in 2.6-fold increase in the percentage of cancer cells with holes. Control untreated cells showed $17.5 \%$ had single holes and $2 \%$ had multiple holes. However, of the L. kefiri P-IF-treated cells, $42 \%$ had single holes and 9.5\% had multiple holes. Fig. 6C shows multiple holes surrounding the nucleus. Some of the holes are highly enlarged, as can be seen in Fig. 6D. The holes were situated in the cytoplasm and the nucleus. Fig. 6D and E also shows that hole induction was associated with membrane blebbing and a decrease in the nuclear to cytoplasmic ratio. These morphological changes are considered to be signs of cancer cell apoptosis. The holes were further characterized by peak force imaging (Figs. 7 and 8), where the variation in size, shape and
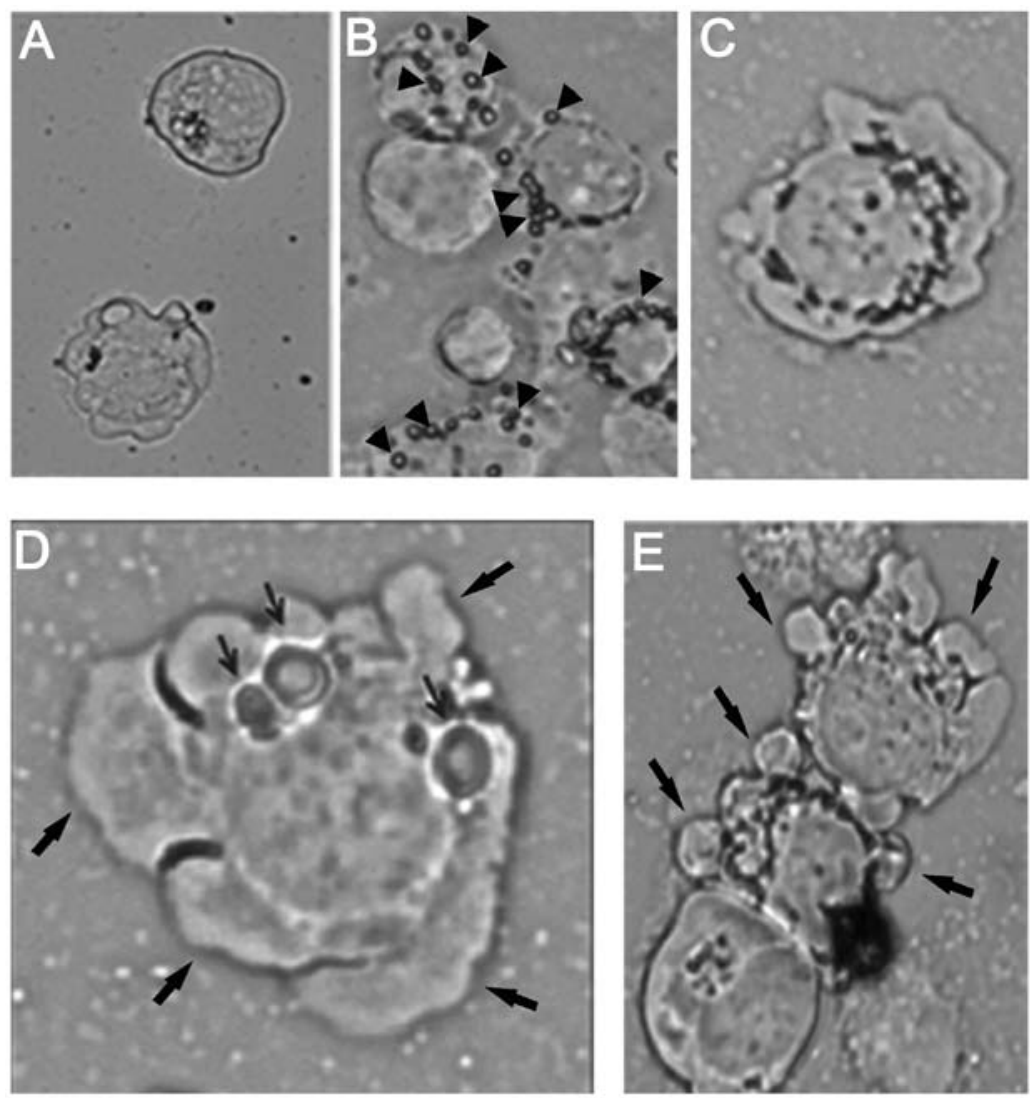

Figure 6. PFT induces holes and membrane blebbing in cancer cells. HL60/AR cells ( $1 \times 10^{6}$ cells $\left./ \mathrm{ml}\right)$ were cultured with PFT and the changes were examined by AFM. (A) Control untreated cells. (B) Cells treated with $5 \mathrm{mg} / \mathrm{ml}$ of PFT for $2 \mathrm{~min}$; note the attachment of cancer cells to $L$ kefiri P-IF (arrowheads). (C-E) Cells treated with $5 \mathrm{mg} / \mathrm{ml}$ of PFT for $24 \mathrm{~h}$; note the presence of extensive holes surrounding the nucleus. (D) A cancer cell with three large holes (thin arrows). (D and E) Membrane blebbing of cancer cells is indicated by thick arrows. Cells were examined using optical imaging. 

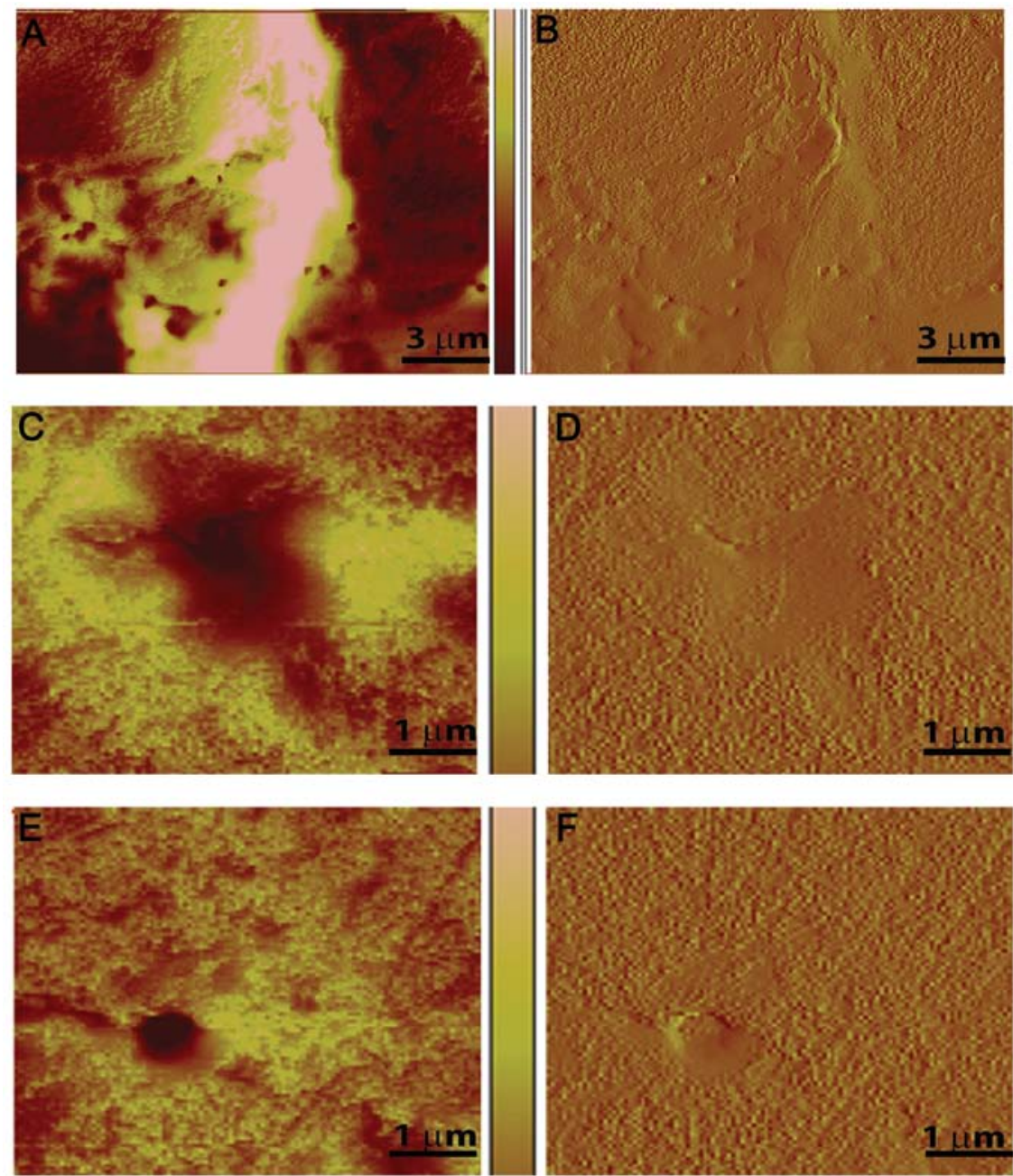

Figure 7. Hole detection using AFM (peak force imaging). Darker color indicates greater hole depth. Note the variation in hole shape, size and depth. (A and B) Several smaller, distinctly circular holes. (C and D) A broad, irregularly shaped, deep indentation. (E and F) A large, circular hole.

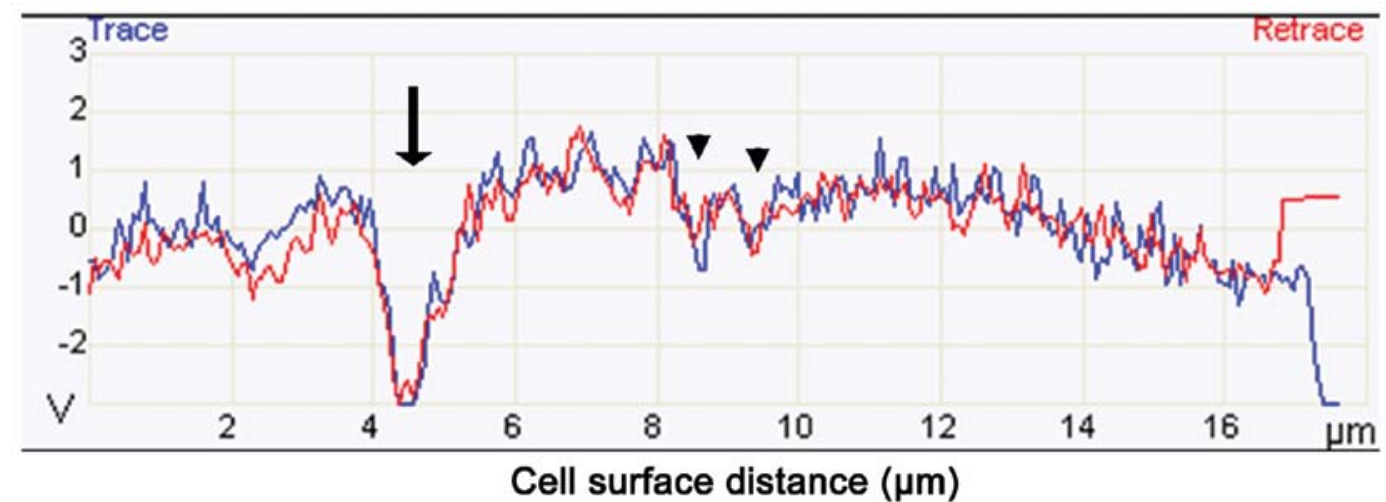

Figure 8. Determining the depth of PFT-induced hole formation. The red and blue lines indicate the surface contour of an HL60/AR cell treated with PFT. The arrow indicates a large hole detected by the SNL tip and arrowheads indicate smaller holes. This image is representative of many HL60/AR cells during PFT treatment.

depth of the holes was measured. The color intensity indicates hole depth, with lighter areas being shallow or flat and darker colors indicating depth (Fig. 7). The topography of the cell was traced using a cantilever tip. The changes in the vertical movement of the SNL tip were recorded and visualized in graphic form as seen in Fig. 8. A decrease along the y-axis indicates the presence of a hole on the surface of the cell. During PFT treatment, many holes were detected in HL60/AR cells using this method of analysis (Fig. 8).

\section{Discussion}

In this study, we examined the apoptotic activity of PFT, a mixture with the main constituent of L. kefiri P-IF. While 
yogurt consumption and exposure to LAB has been shown to exert an inhibitory effect on the growth of different types of cancers $(9,11,14-17)$, no study has examined the apoptotic effects of LAB against MDR cancer cells nor the possible mechanism underlying its effect on these cells. Our results show that PFT has the ability to induce an apoptotic effect on MDR cancer cells in a dose-dependent manner, which is maximal at $67.5 \%$ at concentration of $5 \mathrm{mg} / \mathrm{ml}$. This ability of PFT holds great potential because the development of MDR to chemotherapy by tumor cells presents great obstacles with the current treatment options for cancer. Several drugs have been developed as sensitizers for chemotherapeutics, such as the membrane transporter P-glycoprotein (P-gp) $(24,25)$, 12-deoxyphorbol 13-phenylacetate (26), probenecid (27) and magnetic iron oxide nanoparticles $(28,29)$ but these drugs are toxic.

Several studies have shown that LAB exerts antitumor activity via several mechanisms. These include the ability of LAB for binding mutagens and removing carcinogens from colon $(30,31)$, modulation of different arms of the immune system such as NK cells, dendritic cells, B cells and T cells (32-34) and induction of apoptosis in cancer cells $(18,35,36)$. Results of this study showed an interesting phenomenon whereby L. kefiri P-IF was able to pierce holes in HL60/AR cells. PFT induces apoptosis in HL60/AR cells associated with activation of caspase 3 , decreased expression of $\mathrm{Bcl}-2$ and decrease in the polarization of MMP. This suggests that these holes appear to be responsible for the induction of apoptosis of cancer cells. In addition, AFM studies show that cancer cells with holes are correlated with signs of apoptosis such as membrane blebbing and decrease in the nuclear to cytoplasmic ratio. The mechanism by which uptake of L. kefiri P-IF induces an apoptotic effect on cancer cells may involve $\left[\mathrm{Ca}^{2+}\right] \mathrm{I}$. Our earlier studies showed that human breast cancer MDA-MB-231 cells underwent apoptosis following phagocytosis of heat-killed yeast $S$. cerevisiae (37) by a mechanism that involved the elevation of $\left[\mathrm{Ca}^{2+}\right] \mathrm{I}$. This was evidenced by an increase of $\left[\mathrm{Ca}^{2+}\right] \mathrm{I}$ post-uptake of yeast and also in the inhibition of apoptosis post-addition of 2-aminoethoxydiphenyl borate (2APB), a pharmacological inhibitor of $\mathrm{Ca}^{2+}$ release from the endoplasmic reticulum. We believe that the uptake of L. kefiri P-IF by cancer cells may be responsible for the apoptotic effect by this agent.

Hole piercing has been observed with nanoparticles such as nickel (38) and DPV576, a mixture of nanodiamond and nanoplatinum in liquid (39). It is noteworthy that the hole piercing ability of DPV576 has been associated with reversing drug resistance in HL60/AR cancer cells by increasing the accumulation of chemotherapeautic drugs such as daunorubicin inside cancer cells (39). Therefore, we believe that hole induction by $L$. kefiri P-IF may likewise facilitate the uptake and accumulation of chemotherapeutic drugs by MDR cancer cells, in a manner similar to DPV576 nanoparticles. This is an area for future study.

Vacuoles appear in the cancer cells apparently due to the cells ability to phagocytize microorganisms, such as bacteria and yeast (40-43) and other cells, including: erythrocytes, lymphocytes and neutrophils (44-46). Furthermore, research has also revealed the cannibalistic ability of tumor cells to phagocytize other cancer cells (47). In the present study, we observed that cancer cells treated with L. kefiri P-IF revealed a 2.6-fold increase in the percentage of cells with holes as compared to control untreated HL60/AR cells. This increase was observed in both cancer cells with single as well as multiple holes, which were situated in the cytoplasm and in the nucleus.

The unique properties of the L. kefiri P-IF strain may account for its ability to induce apoptosis in the MDR HL60/ AR leukemic cell line. The specific three-dimensional growth of the P-IF colony indicates that the surface proteoglycans differ from other L. kefiri strains (22). The cell surface of bacteria and other microorganisms are composed of varying polysaccharide-peptide complexes that have been shown to have specific stimulatory effects on host cells that can be beneficial or inhibitory for cell growth (48-50). Further investigation into the unique cell wall components and attributes of L. kefiri P-IF could contribute to a better understanding of the apoptotic induction by cell surface proteoglycans. While not investigated in this study, L. kefiri P-IF has the ability to survive at a low $\mathrm{pH}$, indicating that the $\mathrm{P}$-IF strain remains viable as it travels through the stomach into the intestine, allowing it to continue to grow and provide a protective effect. Some of the protective effects of the P-IF strain may come from its ability to metabolize galactose. High levels of galactose can cause toxicity which could lead to mutations and health problems (51). The presence of $L$. kefiri P-IF in the gut may help to prevent damaging levels of galactose (52). This property warrants future investigation for prevention and maintenance of general health.

L. kefiri P-IF has been shown to be a non-toxic agent. Results of earlier studies in mice treated with L. kefiri P-IF showed that no macroscopic or histopathological abnormalities were detected in different organs post-treatment and no changes in the body weight as compared with control untreated mice (53).

In conclusion, $L$. kefiri $\mathrm{P}$-IF represents a novel symbiotic microbe culture that exerts an apoptotic effect on HL60/AR cells by a mechanism that may involve piercing holes in the cellular membrane of cancer cells. L. kefiri P-IF may represent a new class of adjuvants that could be used to improve the treatment of MDR leukemia.

\section{Acknowledgements}

The authors would like to thank Dr Sastry Gollapudi, Professor of Immunology, Division of Basic and Clinical Immunology, University of California, Irvine, CA, USA for assistance in revision of the manuscript. The authors would also like to thank Paitos Co., Ltd., Yokohama, Kanagawa, Japan; grant no. T0099108. The authors thank Dr Peggy Vorwald for her contributions. The authors acknowledge the use of resources provided by Dr James Gimzewski and for the use of the SPM facility and atomic force microscopy, at the Nano and Pico Characterization Lab at the California NanoSystems Institute.

\section{References}

1. Metchinkoff E and Metchinkoff II: The Prolongation of Life: Optimistic Studies. Putnam, New York, NY, pp109-132, 1908. 
2. Shiby VK and Mishra HN: Fermented milks and milk products as functional foods - a review. Crit Rev Food Sci Nutr 53: 482-496, 2013

3. Ahmed Z, Wang Y, Ahmad A, Khan ST, Nisa M, Ahmad H and Afreen A: Kefir and health: a contemporary perspective. Crit Rev Food Sci Nutr 53: 422-434, 2013.

4. Bianchi-Salvadori B: Intestinal microflora: the role of yoghurt in the equilibrium of the gut ecosystem. Int $\mathbf{J}$ Immunother 11 (Suppl): 9-18, 1986.

5. Kanmani P, Satish Kumar R, Yuvaraj N, Paari KA, Pattukumar V and Arul V: Probiotics and its functionally valuable products - a review. Crit Rev Food Sci Nutr 53: 641-658, 2013.

6. Marco ML,Pavan S and Kleerebezem M: Towards understanding molecular modes of probiotic action. Cur Opin Biotechnol 17: 204-210, 2006

7. Metchnikoff E: Sur le flore du corps humain (On the flora of the Human body). Manch Lit Philos Soc 45: 1-38, 1901.

8. Bergonzelli GE, Blum S, Brussow H and Corthesy-Theulaz I: Probiotics as a treatment strategy for gastrointestinal diseases? Digestion 72: 57-68, 2005.

9. Pala V, Sieri S, Berrino F, Vineis P, Sacerdote C, Palli D, Masala G, Panico S, Mattiello A, Tumino R, Giurdanella MC, Agnoli C, Grioni S and Krogh V: Yogurt consumption and risk of colorectal cancer in the Italian European prospective investigation into cancer and nutrition cohort. Int J Cancer 129: 2712-2719, 2011.

10. Goldin BR, Gualtieri LJ and Moore RP: The effect of Lactobacillus GG on the initiation and promotion of DMH-induced intestinal tumors in the rat. Nutr Cancer 25: 197-204, 1996.

11. Shackelford LD, Rao DR, Chawan CB and Pulasani SR: Effect of feeding fermented milk on the incidence of chemically induced colon tumors in rats. Nutr Cancer 5: 159-164, 1983.

12. Bogdanov IG, Dalev PG, Gurevich LA, Kolosov MN and Malkova VP: Antitumor effect of glycopeptides from the cell wall of Lactobacillus bulgaricus. Biull Eksp Biol Med 84: 709-712, 1977.

13. Biffi A, Coradini D, Larsen R, Riva L and Di Fronzo G: Antiproliferative effect of fermented milk on the growth of a human breast cancer cell line. Nutr Cancer 28: 93-99, 1997

14. Van't Veer P, Dekker JM, Lamars JWJ, Kok FJ and Schouten EG: Consumption of fermented milk products and breast cancer: a casecontrol study in The Netherlands. Cancer Res 49: 4020-4023, 1989.

15. Van't Veer P, van Leer EM, Rietdijk A, Kok FJ, Schouten EG, Hermus RJ and Sturmans F: Combination of dietary factors in relation to breast-cancer occurrence. Int J Cancer 47: 649-653, 1991.

16. Le MG, Moulton LH, Hill C and Kramer A: Consumption of dairy products and alcohol in a case control study of breast cancer. J Natl Cancer Inst 77: 633-636, 1986.

17. Cramer DW, Harlow BL, Willett W, Welch WR, Bell DA Scully RE, Ng WG and Knapp RC: Galactose consumption and metabolism in relation to the risk of ovarian cancer. Lancet 2 : 66-71, 1989.

18. Iyer C, Kosters A, Sethi G, Kunnumakkara AB, Aggarwal BB and Versalovic J: Probiotic Lactobacillus reuteri promotes TNF-induced apoptosis in human myeloid leukemia-derived cells by modulation of NF-kappaB and MAPK signalling. Cell Microbiol 10: 1442-1452, 2008.

19. Chiu YH, Hsieh YJ, Liao KW and Peng KC: Preferential promotion of apoptosis of monocytes by Lactobacillus casei rhamnosus soluble factors. Clin Nutr 29: 131-140, 2010.

20. Hertzler SR and Clancy SM: Kefir improves lactose digestion and tolerance in adults with lactose maldigestion. J Am Diet Assoc 103: 582-587, 2003:

21. Maeda H, Zhu X, Omura K, Suzuki S and Kitamura S: Effects of an exopolysaccharide (kefiran) on lipids, blood pressure, blood glucose, and constipation. Biofactors 22: 197-200, 2004

22. Suzuki K, Tani H, Yabumoto T, Yabumoto Y and Yoshida Y: Novel fermented milk product and use thereof. US Patent No. US 20110123640 A1. May 2011.

23. Sharma S, Rasool HI, Palanisamy V, Mathisen C, Schmidt M, Wong DT and Gimzewski JK: Structural-mechanical characterization of nanoparticle exosomes in human saliva, using correlative AFM, FESEM, and force spectroscopy. ACS Nano 4 : 1921-1926, 2010.

24. Palmeira A, Sousa E, Vasconcelos MH and Pinto MM: Three decades of P-gp inhibitors: skimming through several generations and scaffolds. Curr Med Chem 19: 1946-2025, 2012

25. Binkhathlan Z and Lavasanifar A: P-glycoprotein inhibition as a therapeutic approach for overcoming multidrug resistance in cancer: current status and future perspectives. Curr Cancer Drug Targets 13: 326-346, 2013.
26. Gollapudi S, Singh H and Gupta S: Effect of 12-deoxyphorbol 13-phenylacetate on daunorubicin resistance and calciumindependent protein-kinase-C isozymes in drug-sensitive murine leukemia p388 cells. Int J Oncol 4: 849-851, 1994.

27. Gollapudi S, Kim CH, Tran BN, Sangha S and Gupta S: Probenecid reverses multidrug resistance in multidrug resistance-associated protein-overexpressing HL60/AR and H69/AR cells but not in P-glycoprotein-overexpressing HL60/Tax and P388/ADR cells. Cancer Chemother Pharmacol 40: 150-158, 1997.

28. Lai BB, Chen BA, Cheng J, Gao F, Xu WL, Ding JH, Gao C, Sun XC, Li GH, Chen WJ, Liu LJ, Li XM and Wang XM: Daunorubicin-loaded magnetic nanoparticles of $\mathrm{Fe}(3) \mathrm{O}(4)$ greatly enhance the responses of multidrug-resistant K562 leukemic cells in a nude mouse xenograft model to chemotherapy. Zhongguo Shi Yan Xue Ye Xue Za Zhi 17: 345-351, 2009.

29. Cheng J, Wang J, Chen B, Xia G, Cai X, Liu R, Ren Y, Bao W and Wang $X$ : A promising strategy for overcoming MDR in tumor by magnetic iron oxide nanoparticles co-loaded with daunorubicin and 5-bromotetrandrin. Int J Nanomedicine 6: 2123-2131, 2011.

30. Tavan E, Cayuela C, Antoine JM, Trugnan G, Chaugier C and Cassand P: Effects of dairy products on heterocyclic aromatic amine induced rat colon carcinogenesis. Carcinogenesis 23: 477-483, 2002.

31. Lidbeck A, Nord CE, Gustafsson JA and Rafter J: Lactobacilli, anticarcinogenic activities and human intestinal microflora. Eur J Cancer Prev 1: 341-353, 1992.

32. Link-Amster H, Rochat F, Saudan KY, Mignot O and Aeschlimann JM: Modulation of a specific humoral immune response and changes in intestinal flora mediated through fermented milk intakes. FEMS Immunol Med Microbiol 10: 55-64, 1994.

33. Tsai YT, Cheng PC and Pan TM: The immunomodulatory effects of lactic acid bacteria for improving immune functions and benefits. Appl Microbiol Biotechnol 96: 853-862, 2012.

34. Hong WS, Chen YP and Chen MJ: The antiallergic effect of kefir Lactobacilli. J Food Sci 75: H244-H253, 2010.

35. Perdigon G, de Moreno de LA, Valdez J and Rachid M: Role of yoghurt in the prevention of colon cancer. Eur J Clin Nutr 56 (Suppl 3): S65-S68, 2002.

36. Altonsy MO, Andrews SC and Tuohy KM: Differential induction of apoptosis in human colonic carcinoma cells (Caco-2) by Atopobium, and commensal, probiotic and enteropathogenic bacteria: mediation by the mitochondrial pathway. Int J Food Microbiol 137: 190-203, 2010.

37. Ghoneum M, Matsuura M, Braga M and Gollapudi S: S. cerevisiae induces apoptosis in human metastatic breast cancer cells by altering intracellular $\mathrm{Ca}^{2+}$ and the ratio of Bax and Bcl-2. Int J Oncol 33: 533-539, 2008.

38. Guo D, Wu C,Li J, et al: Synergistic effect of functionalized nickel nanoparticles and Quercetin on inhibition of the SMMC-7721 cells proliferation. Nanoscale Res Lett 4: 1395-1402, 2009.

39. Ghoneum A, Sharma S and Gimzewski J: Nano-hole induction by nanodiamond and nanoplatinum liquid, DPV576, reverses multidrug resistance in human myeloid leukemia (HL60/AR). Int J Nanomed 8: 2567-2573, 2013.

40. Vandenberghe J, Verheyen A, Lauwers S and Geboes K: Spontaneous adenocarcinoma of the ascending colon in Wistar rats: the intracytoplasmic presence of a Campylobacter-like bacterium. J Comp Pathol 95: 45-55, 1985.

41. Ghoneum M, Grewal I, Brown J, Osborne R, Elembabi H and Gill G: Phagocytosis of candida albicans by lymphatic tumour cells in vitro. Acta Histochem 105: 127-133, 2003.

42. Ghoneum M and Gollapudi S: Phagocytosis of Candida albicans by metastatic and non metastatic human breast cancer cell lines in vitro. Cancer Detect Prev 28: 17-26, 2004.

43. Ghoneum M, Hamilton J, Brown J and Gollapudi S: Human squamous cell carcinoma of the tongue and colon undergoes apoptosis upon phagocytosis of Saccharomyces cerevisiae, the baker's yeast, in vitro. Anticancer Res 25: 981-989, 2005.

44. Ghoneum M, Salem F, Shum SS, Perry L and Gill G: In situ lymphophagocytosis by nonlymphoreticular neoplasms. Nat Immun Cell Growth Regul 6: 77-87, 1987.

45. Ghoneum M, Salem F, Allen H and Gill G: Phagocytosis of autologous lymphocytes by cervical preneoplastic and neoplastic cells. Nat Immun Cell Growth Regul 7: 239-248, 1988.

46. Singhal N, Handa U, Bansal C and Mohan H: Neutrophil phagocytosis by tumor cells - a cytological study. Diagn Cytopathol 39: 553-555, 2011. 
47. Overholtzer M, Mailleux AA, Mouneimne G, et al: A nonapoptotic cell death process, entosis, that occurs by cell-in-cell invasion. Cell 131: 966-979, 2007.

48. Kogan G, Pajtinka M, Babincova M, Miadokova E, Rauko P, Slamenova D and Korolenko TA: Yeast cell wall polysaccharides as antioxidants and antimutagens: can they fight cancer? Neoplasma 55: 387-393, 2008.

49. Cattaruzza S, Nicolosi PA and Perris R: Proteoglycans in the control of tumor growth and metastasis formation. Connect Tissue Res 49: 225-229, 2008.

50. Oh JY, Baek YM, Kim SW, Hwang HJ, Hwang HS, Lee SH and Yun JW: Apoptosis of human hepatocarcinoma (HepG2) and neuroblastoma (SKN-SH) cells induced by polysaccharidespeptide complexes produced by submerged mycelial culture of an entomopathogenic fungus Cordyceps sphecocephala. J Microbiol Biotechnol 18: 512-519, 2008.
51. Lai K, Elsas LJ and Wierenga KJ: Galactose toxicity in animals. IUBMB Life 61: 1063-1074, 2009.

52. Davit-Spraul A, Pourci ML, Soni T and Lemonnier A: Metabolic effects of galactose on human HepG2 hepatoblastoma cells. Metabolism 43: 945-952, 1994.

53. Paitos Co., Ltd. Yokohama, Kanagawa, Japan. Increase the good bacteria held by nature, ideal AH21 is a functional food, consider preventive medicine and food. http://www.bio-j.net/ken00.html. Accessed June 14, 2013. 